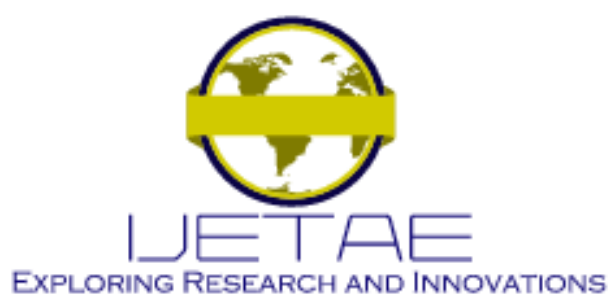

International Journal of Emerging Technology and Advanced Engineering

Website: www.ijetae.com (E-ISSN 2250-2459, Scopus Indexed, ISO 9001:2008 Certified Journal, Volume 11, Issue 08, August 2021)

Manuscript Received: 27 June 2021, Received in Revised form: 03 August 2021, Accepted: 16 August 2021～DOI: 10.46338/ijetae0821_08

\title{
The Determinant Factors of Food and Beverage Small and Medium Industries Competitive Advantage that Mediated by E-Commerce Adoption Level in Bogor
}

\author{
Ayuningtyas Octora ${ }^{1}$, Heri Kurniawan ${ }^{2}$, Luqman Fadhil Gultom ${ }^{3}$, Arta Moro Sundjaja ${ }^{4}$ \\ 1,2,3,4 Business Management Program, Management Department, BINUS Business School Master Program, Bina Nusantara \\ University, Jakarta, Indonesia, 11480
}

\begin{abstract}
The research aims to examine the determinant factors of culinary Small-and-Medium Industries (SMIs) competitive advantage that mediated by e-commerce adoption level in Bogor. This research uses a quantitative approach using Structural Equation Modelling. The primary data is collected using online questionnaires. The population size is 360 culinary SMIs that already used e-commerce. The sampling technique is using purposive sampling. The sample size determination method is using Slovin's formula with $\mathbf{8 5 \%}$ confidence level and the sample size in this study is $\mathbf{4 2}$ culinary founders. The data analyse using Smart PLS 3.0. Based on the data analysis, the top management is the only determine the SMIs to adopt e-commerce for each ecommerce adoption level. For adoption level 1, the ecommerce adoption affects growth and quality. For adoption level 2, the e-commerce adoption affects quality, growth, and differentiation. For adoption level 3, the e-commerce adoption affect growth. For adoption level 4, the e-commerce adoption affects growth, differentiation, quality, and cost reduction. the e-commerce adoption level, the cost reduction, company differentiation, sales growth, and quality.
\end{abstract}

Keywords - Small-and-Medium Industry; culinary industry; e-commerce adoption level; TechnologyOrganization-Environment; competitive advantage

\section{INTRODUCTION}

Micro, Small, and Medium-sized Enterprise (MSME) is one of the sectors that can be relied on in crisis times because of its resistant nature and its significant contribution to a country's economy [1]. MSMEs in Indonesia are still in the growing phase and currently providing a massive portion to the country's Gross Domestic Product (GDP). Similarly, Small and Mediumsize Industries (SMIs) also have a positive trend and give rise to GDP from the creative economy sector.

Culinary is a business sector that accommodates humans' primary needs. Therefore, this sector will always be in demand.
Based on data from the Creative Economic Agency and the Center of Statistic Agency (BPS) 2018, the culinary industry contributes 41.4 percent of tourism and creative economy revenue, which equals 410 trillion rupiahs. BPS data 2020 also shows that the culinary sector constitutes the largest SMIs with 1.6 million business units.

The massive development of culinary business and information technology affects businesses to use ecommerce as their selling platform. E-commerce contributes to Indonesia's GDP growing exponentially every year. [2] stated that in the short-term, there would be an increase of Rp. 491 million in GDP for every new ecommerce.

E-commerce offers great business opportunities due to people's response to the business model. It provides users with unlimited product options, information screening, product comparison, and timesaving, ultimately affecting the decision-making duration [3]. It is important to businesses, especially during the COVID-19 outbreak, where the government restricts physical-contact activities. As the role of e-commerce is to connect businesses and customers online, this will open a new market venue for conventional food and beverage SMIs and help them reach more customers through its broad network [4]; [5]. If utilized at its highest level, e-commerce can help businesses increase their competitiveness in the market.

SMIs in Bogor have been affected differently by the pandemic as other regions in Indonesia. During the COVID-19 breakout, their sales increased $200 \%$ on average. However, this sales growth is distributed unevenly among business units. One of the factors that affect the sales growth difference is the contrasting ability in operating and marketing their products and services in ecommerce. Therefore, it is vital to analyse the e-commerce level adoption to even the operational ability among SMIs. Thus, researching the key factors that might affect SMIs in adopting e-commerce is essential. 


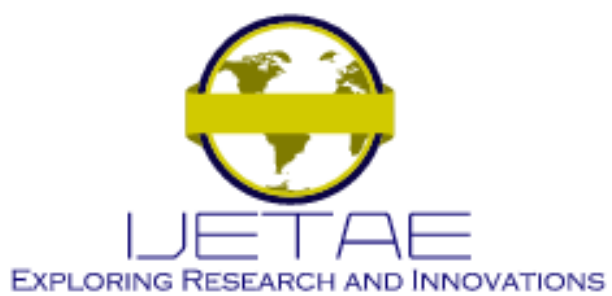

International Journal of Emerging Technology and Advanced Engineering

Website: www.ijetae.com (E-ISSN 2250-2459, Scopus Indexed, ISO 9001:2008 Certified Journal, Volume 11, Issue 08, August 2021)

According to [4], there are four e-commerce adoption levels of a business unit: Level I, presence; Level II, portals; Level III, transaction integration; Level IV, enterprise integration. A business that has not adopted ecommerce is called a non-adopter. Many internal factors might affect the e-commerce adoption level by a business. Therefore, analysing the e-commerce adoption level by food and beverages businesses can be done by looking into several factors that might significantly affect it. Information and communication technology (ICT) is constantly evolving to create more competitiveness for businesses, and there is a need for SMIs to plan and implement new strategies. ICTs have become a catalyst for business processes, become a supporting tool for managing businesses, leverage development strategies to achieve competitive advantage and innovation in business operations, and bring sustainability to SMIs over time [6].

The determinants factor of e-commerce adoption in SMEs refer to several theories, one of which is the technological, organizational and environmental (TOE) theory. Previous research belongs to [6] and [7] has discussed the adoption of e-commerce at levels I to IV. [6] research focuses on several factors that play a role in influencing the adoption of e-commerce at levels I to IV which consist of technology factors, organization, and environment.

Then proprietary research [7] plays a role in analyzing how each level of e-commerce adoption affects the benefits that may arise from e-commerce adoption on competitive advantage in a business. Both of these studies use the level of adoption of e-commerce. Then the authors in this study try to combine these two studies and analyze the role of the factors that influence the adoption of e-commerce and the impact of e-commerce adoption at each level on the competitive advantage of a Culinary IKM business in Bogor City. [8] revealed that the available advantages of ecommerce depend on the level of adoption by SMEs. The extent to which SMEs are prepared to adopt B2B ecommerce is commensurate with the adoption benefits they derive.

SMIs e-commerce adoption level factors refer to several theories. One of them is the technological, organizational, and environmental (TOE) theory. On the technology side, technology is one factor that pushes businesses to innovate and adopt e-commerce [9]. Another research also argue that innovation can transform conventional businesses into businesses that adopt internet-based information and communication technology and help them get leverage from their competitors [10].
The organization also has a role in the decision to adopt e-commerce by a company. A company is a dynamic organization that uses adjustment to help them compete with others, including adopting e-commerce [11]. This role also includes resources preparation such as financial and workforce to transition from conventional business to ecommerce [12]. Besides technology and organization, the environment also holds a vital role in influencing businesses into adopting e-commerce. In this context, the environmental factors are external factors such as pressure from suppliers and customers or competitors. [13] stated that the higher the business partner's pressure, the more likely a business would adopt e-commerce and hold its competitive position.

In [6] research, the questionnaire was utilized to obtain information from manufacturing SME owners and managers. The study used the National Board for SmallScale Industries, the Registrar General Department, the Association of Ghana Industries, and the Global Business Directorate databases to randomly pick 1,124 Ghanaian manufacturing SMEs as the sample frame. These agencies' data might be accessible through their websites. A representative sample of 648 manufacturers with websites was also picked using a systematic random method, considering the aggregation of product type and geographic regions as stratification factors. Greater Accra, Western, Ashanti, and Eastern were the four geographic areas studied out of the ten regions in Ghana (at the time of data collection; there are now 16 regions in Ghana).

In [7] research adopted a mixed-methods strategy. A questionnaire survey was utilized to obtain data from SME owners/managers in the manufacturing sector in both the United States and Egypt. The study chose 1,280 manufacturing SMEs in the United States and 1,280 manufacturing SMEs in Egypt at random. A total of 320 valid and missing data-free responses from the United States and 200 from Egypt were gathered, resulting in a response rate of $25 \%$ for the United States and $26 \%$ for Egypt. The categorization of eBPs was used to determine the amount of B2B e-Commerce adoption.

Previous research has limitations since it focuses mostly on manufacturing SMEs. Only the respondents' opinions, attitudes, and experiences with B2B e-commerce adoption at a certain moment in time are reflected in the crosssectional survey. Another drawback is that the study excludes elements that may explain why SMEs do not reach higher levels of adoption, such as in the case of Egyptian SMEs, which lag their developed counterparts. 


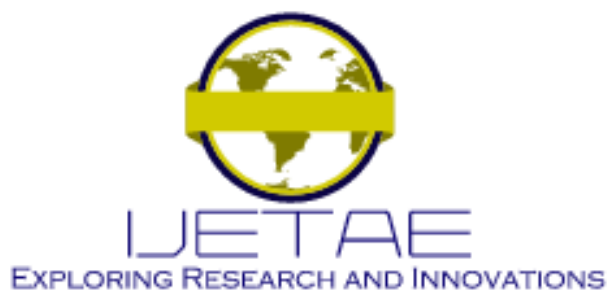

International Journal of Emerging Technology and Advanced Engineering

Website: www.ijetae.com (E-ISSN 2250-2459, Scopus Indexed, ISO 9001:2008 Certified Journal, Volume 11, Issue 08, August 2021)

Based on the research limitation from [6] and [7], the researchers develop comprehensive model that accommodate Technology, Organization, and Environment as determinant factors of e-commerce adoption level and cost reduction, differentiation, growth, and quality as competitive advantage of e-commerce adoption. The research objective is examining the determinant factors of culinary Small-and-Medium Industries (SMIs) competitive advantage that mediated by e-commerce adoption level in Bogor.

\section{LITERATURE STUDY}

\section{E-commerce Adoption Level}

[14] stated that based on the e-gov model, e-commerce adoption level consists of four levels, and a business that is yet to adopt e-commerce is called non-adopter.

Level 1 (Presence) is an adoption level where a business unit uses a website, including social media, such as Facebook, Twitter, and Instagram, to initiate a one-way communication to give their products and services information.

Level 2 (Portals) is an adoption level where a business unit not only uses a website, including social media, to communicate with customers and suppliers to give information about their products and services. In addition, the business unit on the portals level also provides additional services for customers, including order customization and asking for feedback on their products and services using the website.

Level 3 (Transaction Integration) is an adoption level where a business unit uses a website and social media not only for communicating with customers and suppliers, giving information about products and services, providing order customization, and processing feedback. The business unit also provides the customers with online payment service (integrated with the bank system) or online order features like shopping carts.

Level 4 (Enterprise Integration) is the highest adoption level where all transaction and communication of a business unit is centralized in the website. The business unit utilizes a website, including social media, to share information and communicate with customers and suppliers.
However, they also add other services such as give information about the products and services, communicating with suppliers and customers, providing additional services to the customers such as order customization, taking feedback, providing online payment and/or online order, integrating the internal process with online booking, and implementing Supplier Relationship Management (SRM) and Customer Relationship Management (CRM).

\section{TOE Theory as E-commerce Adoption Driving Factor}

Technology Organizational Environment (TOE) Theory offers three main aspects to explore factors that affect an organization in accepting innovation in technology, such as e-commerce adoption in the business unit [15].

\section{Technology}

Technology is any process by which one party gains access to another party's technical information and manages to learn and absorb it into the production function. It is undeniable the importance of technology as one of the elements that increase the productivity of a company. In a highly competitive environment, managers are required to use the optimal technology for their company[16]. According to [12], the technological factors consist of several indicators, for example, the perceived benefits, suitability, and cost influence the decision to adopt ecommerce. [17] argue that perceived benefits are the main reason an organization wants to adopt e-commerce. The more significant the benefit, the stronger the reason to use e-commerce. Hence, significantly impacting the adoption level [18]. The argument is supported by [19]. They stated that perceived desirability is the fundamental factor of adopting a technology. Therefore, this research proposes the following hypothesis:

H1: The perceived desirability positively impacts the ecommerce adoption level.

\section{Organization}

Organizing is a social process, which involves the interaction of different people with different interests, priorities, and needs. The company's organizational factors can influence the decision of whether they will adopt ecommerce. 


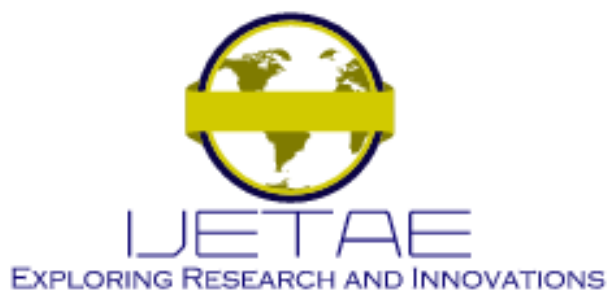

International Journal of Emerging Technology and Advanced Engineering

Website: www.ijetae.com (E-ISSN 2250-2459, Scopus Indexed, ISO 9001:2008 Certified Journal, Volume 11, Issue 08, August 2021)

Based on [12], one of the organizational aspect indicators is the company's readiness to use technology. The preparedness indicates how far the technology infrastructure is compatible with the system and the technical ability to adopt e-commerce [12].

[6] add that the organization's readiness shows that the company has its resources aligned with its objective in adopting the technology. [18] stated that the organization's readiness is considered one of the most decisive factors that affect the business unit's decision to e-commerce. Hence, this research proposes the following hypothesis:

$\mathrm{H} 2$ : Organization's readiness positively impacts the ecommerce adoption level.

Other than the organization's readiness, top management support is also included in the organizational aspect. Top management's commitment is influential in supporting the cultural changes in management style, result management, changes in work practice, and the need for technology and communication shift support [18]. top management support significantly affects the decision to adopt e-commerce because their support means approval; [6]. Thus, this research proposes the following hypothesis:

H3: Top management support positively affects ecommerce adoption level.

\section{Environment}

The environment is classified as the external factor that influences a company's decision to adopt e-commerce [20]. Those external factors include market competition and competitive drive as [21] stated that external competition has a considerable effect on e-commerce adoption. Exclusively, [5] mentioned that competitive pressure forces an organization to follow the status quo, in this case, adopting e-commerce. Therefore, this research proposes the following hypothesis:

H4: Competitive pressure positively impacts e-commerce adoption level.

Another indicator from the environmental aspect is a business partner. A business partner is an external factor that forces a company to consider changes to be relevant and competitive [20]. Based on [21], success in adopting ecommerce relied upon business partner's readiness to adopt e-commerce to support business operations. Accordingly, this research proposes the following hypothesis:

H5: Business partner pressure positively impact ecommerce adoption level.
Support from the government is also included in the environmental aspect. The government support in technology infrastructure, policy, and funding positively affects technology adoption [22]. Some of the previous papers suggest that the government has a notable impact on e-commerce adoption. Wherefore, this research proposes the following hypothesis:

H6: Government support positively impacts e-commerce adoption.

\section{Competitive Advantage}

Information technology is one of the areas associated with competitive advantage for SMEs. One of the goals of using IT is to support the survival of companies by using Internet technology to stay ahead of competitors and differentiate their position in the global market [7]. In the area of human resources and capabilities, both technological and managerial capabilities have been analysed and realized following criteria that focus on the importance of competitive advantage and its sustainability[23], [24]. By introducing the most appropriate technology, it should be able to reduce costs and improve quality [16]. Through technology, firms create value, as well as capacity for development, specialization, and ultimately create a competitive advantage for the firm [25].

In a previous study of UK SMEs, [26] found that ecommerce helps SMEs create a competitive advantage. Later in his study of SMEs [7] which compared the use of information technology in e-commerce adoption at adoption levels I to IV found that small and medium-sized enterprises can achieve growth in market share and sales, which helps them improve their position in global markets through higher adoption rates of business-to-business ecommerce. This study is an elaboration of previous research, the same as the research owned by [7] this study measures competitive advantage with a construct consisting of cost reduction, differentiation, sales growth, and quality.

\section{Cost Reduction}

The function of price is to inform people about the value of goods or services. Price is defined as one of the nonproduct attributes of brand associations that can be an important association in the formation of brand perceptions, especially those related to values and desires and is a criterion that consumers often use to share their knowledge about a market or category. 


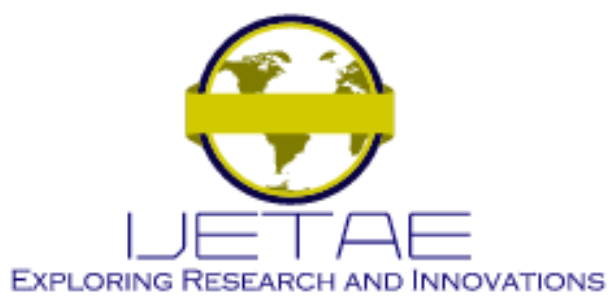

International Journal of Emerging Technology and Advanced Engineering

Website: www.ijetae.com (E-ISSN 2250-2459, Scopus Indexed, ISO 9001:2008 Certified Journal, Volume 11, Issue 08, August 2021)

A business unit's performance in finance is affected by e-commerce adoption. [7] argue that e-commerce adoption can reduce cost and increase its quality. Cost reduction is one of the competitive advantages of adopting e-commerce [27]. [28] adds that e-commerce adoption is proven to reduce marketing, advertising, and selling costs. So, this research proposes the following hypothesis:

H7: E-commerce adoption level has a positive impact in reducing cost.

\section{Differentiation}

Besides finance, Michael Porter in [29] considers differentiation as a strategic basis that can help a company to achieve competitive leverage [29]. [29] defines differentiation as a company strategy to create a product that can provide a unique proposition and is eligible for a very flexible market. Some companies partner with ecommerce to create differentiation and build leverage to increase their competitiveness by creating unique features such as product warranty [30], chat [31], bid [32], followers [33], hashtag [33], and integration to social media [33]. Ref [34] find that optimizing e-commerce improves a company's competitiveness significantly by increasing in differentiation. Thus, this research proposes the following hypothesis:

H8: E-commerce adoption level has a positive impact on a company's differentiation.

\section{Sales Growth}

Sales growth is also a competitiveness indicator of an industry. A company's growth would affect its ability to retain profit by funding future opportunities. According to [35], an increase in growth indicates an increase in its revenue. Furthermore, [36] proves that e-commerce positively impacts MSMEs' revenue. Hence, this research proposes the following hypothesis:

H9: E-commerce adoption level positively impacts sales growth.

\section{Quality}

A company's quality, such as good products and services, reliable information, good relations with business partners, and remarkable customer service, can affect its performance.
Technology and communication can help a company retain and improve its reputation and service quality [37], receive feedback [37], reduce cost [38], build better coordination [38], establish a good relationship with its customers [37], and maintain a good relationship with business partners [38]. Thus, this research proposes the following hypothesis:

H10: E-commerce adoption level positively impacts quality.

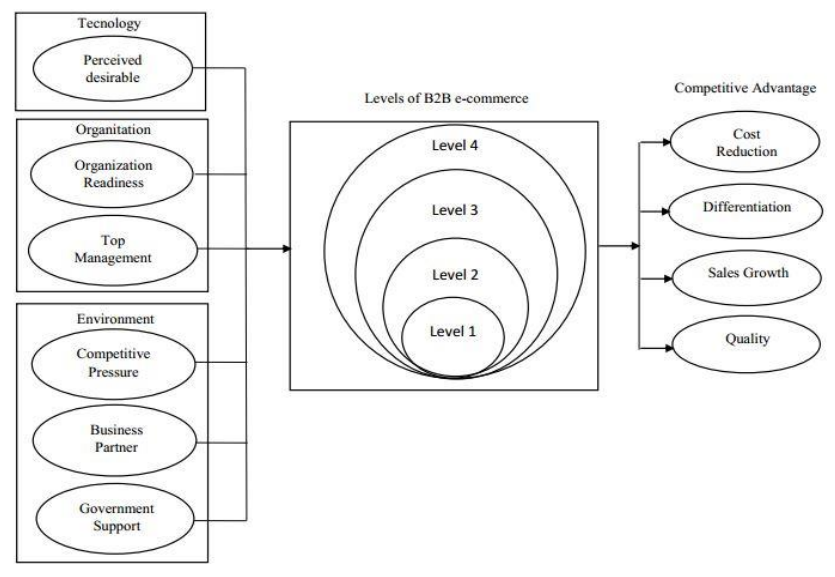

Figure 1. Proposed Research Model

\section{Methodology}

The research design is quantitative method. The data analysis method is Structural Equation Modelling using Smart PLS 3.0. The data collection method is questionnaire. The population size is 360 SMIs in Bogor which already adopted e-commerce in their daily operation. The population size information is provided by Ganjar Gunawan, Head of Industry and Trade of Bogor using interview method. Based on adoption stratification from [4], the SMIs business units that are analyzed are those who already adopt e-commerce, with a minimum of Level 1.

The minimum sample quantity is determined by using the Slovin equation [1] with a confidence level at least $85 \%$. Therefore, the sample size are 42 respondents. The unit of analysis is the culinary founder. The sampling technique is snowball sampling. The data is collected using a one-shot (cross-sectional) questionnaire because the data range that is wished to be collected in the present data, not progressive data (Sekaran \& Bougie, 2016). 


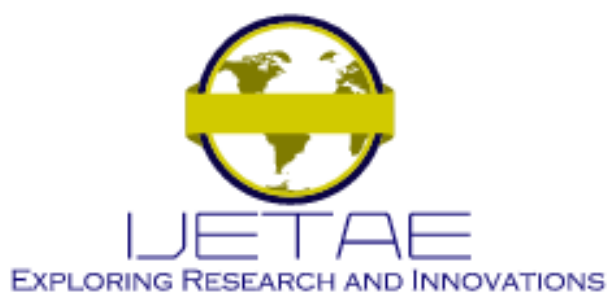

International Journal of Emerging Technology and Advanced Engineering

Website: www.ijetae.com (E-ISSN 2250-2459, Scopus Indexed, ISO 9001:2008 Certified Journal, Volume 11, Issue 08, August 2021)

The measurement of variables was adopted from the previous research, translated from English to Bahasa Indonesia. This research is the development of [6] and [7] research. The independent variable in this study is the TOE framework which consists of technology, organizational, dan environment [6]. The technology subvariable is measured by one dimension, namely perceived desireability. Organizational sub-variables consist of two dimensions, namely organizational readiness as measured by the use and support of top management. The environmental sub-variable consists of three dimensions, namely competitive pressure, business partner's pressure, and government support. Research conducted by [6] provides a perspective on the role of technological factors, organizational factors, and environmental factors in the desire of a company to adopt e-commerce.

The variable of e-commerce adoption which is the intervening variable aims to be a link between the independent variable and the dependent variable. B2B adoption levels categorize four different levels, adopted from [7] and [6]. The adoption of e-commerce has four levels where the higher the level, the level of adoption will be stronger. There are four levels of e-commerce adoption according to [6]. The level of adoption of e-commerce according to [4] is divided into four levels. The point is that there are 4 levels of adoption level and 1 level without adopting e-commerce. The level of e-commerce adoption is the presence level, portal level, transaction integration level, and the highest level is level 4 as enterprise integration.

While the dependent variable in this study is competitive advantage as measured by four sub-variables, namely cost reduction, differentiation, growth and high product quality adopted from [7]. The data obtained in this study used a questionnaire distributed via an online link.

The questionnaire contains several questions with answer choices using a Likert scale (Strongly Disagree (1) Strongly Agree (5)). Data collection was carried out by distributing questionnaires via google form to 42 Culinary IKMs in Bogor City from January to February in 2021. In the process of distributing questionnaires, the authors received enormous help and support from Ganjar Gunawan as Head of the Bogor City Industry and Trade Department. He gave directions to Dede Asiir who served as Head of the Trade and E-Commerce Division of the Bogor City Industry and Trade Department so that he could assist the process of distributing the questionnaire to 42 respondents of Culinary IKM member in Bogor City.
With the mandate and direction of Ganjar Gunawan, Dede Asiir also played a role in helping the author to ensure that 42 members of the Bogor City Culinary IKM member who acted as respondents in this study were able to fill out the questionnaire correctly and according to the actual situation.

The e-commerce adoption level indicators was adopted from [7] and [6]. The e-commerce adoption has four level. The higher the level, the more advanced the e-commerce adoption [6]. Those levels are Level 1: presence; Level 2: portals; Level 3: transaction integration; and Level 4: enterprise integration; and non-adopter level [6]; [4]. According to [7], the competitive advantage explained using cost reduction, differentiation, growth, and product quality.

\section{RESULTS}

\section{Measurement Model Assessment}

The researchers tested the instrument quality with a validity and reliability test. Even though qualitatively, the test's questions and statements are valid, they are subject to the respondents' interpretation. Wherefore, this research only uses the responses that have been identified through a validity test. This research uses face validity and construct validity as the validity test. The face validity test is based on the judgement or appraisal from the academic advisors as expertise. The face validity test is used to measure every question and statement qualitatively since they cannot be measured by statistical processing tools [39], and the construct validity test is used by correlating the statements in a questionnaire with the total score [40]. The correlation score between statements compared to the total minimum is 0,3 or $30 \%$, meaning the correlation of every statement compared to the total score is $30 \%$.

The reliability test is essential to ensure that every statement item is consistent in measuring a particular item. This research uses internal consistency based on Cronbach's Alpha value. the Cronbach's Alpha cut-off value is 0,6 .

The hypothesis testing will provide the 'goodness of fit' value or acceptability of the research model based on structure and the coefficient of determination. The coefficient of determination shows the impact of each hypothesis. The closer the value to 1 (in decimal) or 100 (in percentage), the more capable the variable is to explain another variable, and vice versa. 


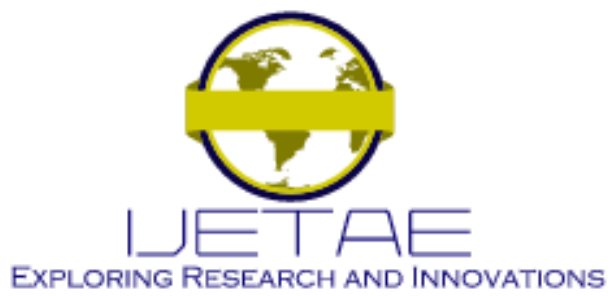

International Journal of Emerging Technology and Advanced Engineering

Website: www.ijetae.com (E-ISSN 2250-2459, Scopus Indexed, ISO 9001:2008 Certified Journal, Volume 11, Issue 08, August 2021)

Table 1.

Demographic Characteristic of Respondents

\begin{tabular}{lccc}
\hline Characteristic & Details & Frequency & Percent \\
\hline Gender & Male & 6 & $14,3 \%$ \\
& Femate & 36 & $85,7 \%$ \\
Age & $\leq 20$ & & \\
& $21-$ & 4 & $9,5 \%$ \\
& 40 & 13 & $31,0 \%$ \\
& $41-$ & 24 & $57,1 \%$ \\
& 60 & 1 & $2,4 \%$ \\
Type of & $>60$ & & \\
Industry & Food & 42 & $100,0 \%$ \\
& & & $0,0 \%$ \\
\hline \multirow{2}{*}{ Drink } & & &
\end{tabular}

The instrument validity is shown as the AVE value on the table. The value is used to measure the variance quantity that construct can be captured compared to the variance that is resulted from measurement error, which means the variance value in each variable is still measuring those variables.
The AVE's required value is $>0,5$, and the result shows that all variables have AVE values over 0,5. Therefore it concludes that each variable can capture the data variance.

Reliability is the measurement of internal consistency of construct indicators indicating the degree to which each indicator indicates common latent factors or a construct. The reliability test is done by looking for the Cronbach's Alpha, Rho A, and Composite Reliability value. The Cronbach's Alpha, Rho A, or Composite Reliability will show good reliability if the value is more than 0,7 . The test result exhibit all variables have Cronbach's Alpha, Rho A, and Composite Reliability above 0,7 , which means all the variables are reliable where all indicators' measurement is consistent.

Based on the multicollinearity test, there are many multicollinearity violations according to the VIF measurement. Thus, the research eliminates the variables with a value above five. Table 3 shows the variables that qualified for the multicollinearity test. These data were then used in the hypothesis test with Structural Equation Modelling with Partial Least Square model.

Table 2.

Reflective latent variable value measurement

\begin{tabular}{llcccc}
\hline Group (levels) & Construct & Cronbach's Alpha & Rho A & Comp. Reliability & AVE \\
\hline & Adoption Factors (TOE) & & & & \\
& Perceived Desirable & 0.798 & 0.833 & 0.866 & 0.619 \\
& Organization Readiness & 0.871 & 0.964 & 0.937 & 0.882 \\
& Top Management & 0.808 & 0.988 & 0.843 & 0.581 \\
& Competitive Pressure & 0.823 & 0.868 & 0.879 & 0.650 \\
Level 1 & Business Partner & 0.854 & 0.874 & 0.901 & 0.695 \\
& Government Support & 0.892 & 0.932 & 0.924 & 0.754 \\
& SMEs Performances & & & & 0.690 \\
& Cost Reduction & 0.888 & 0.922 & 0.917 & 0.719 \\
& Differentiation & 0.912 & 1.004 & 0.927 & 0.863 \\
& Sales Growth & 0.841 & 0.843 & 0.927 & 0.787 \\
\hline Quality & 0.885 & 1.398 & 0.917 & 0.607 \\
& Adoption Factors (TOE) & & & & 0.703 \\
& Perceived Desirable & 0.798 & 0.863 & 0.860 & 0.551 \\
& Organization Readiness & 0.824 & 1.086 & 0.876 & 0.650 \\
& Top Management & 0.808 & 1.012 & 0.822 & 0.694 \\
& Competitive Pressure & 0.823 & 0.879 & 0.879 & 0.744 \\
& Business Partner & 0.854 & 0.983 & 0.900 & 0.737 \\
& Government Support & 0.892 & 0.981 & 0.920 & \\
& SMEs Performances & & & & 0.933 \\
\end{tabular}




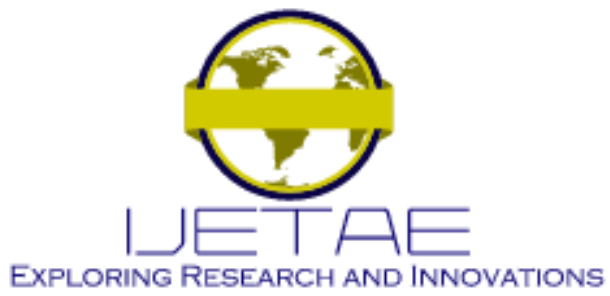

International Journal of Emerging Technology and Advanced Engineering

Website: www.ijetae.com (E-ISSN 2250-2459, Scopus Indexed, ISO 9001:2008 Certified Journal, Volume 11, Issue 08, August 2021)

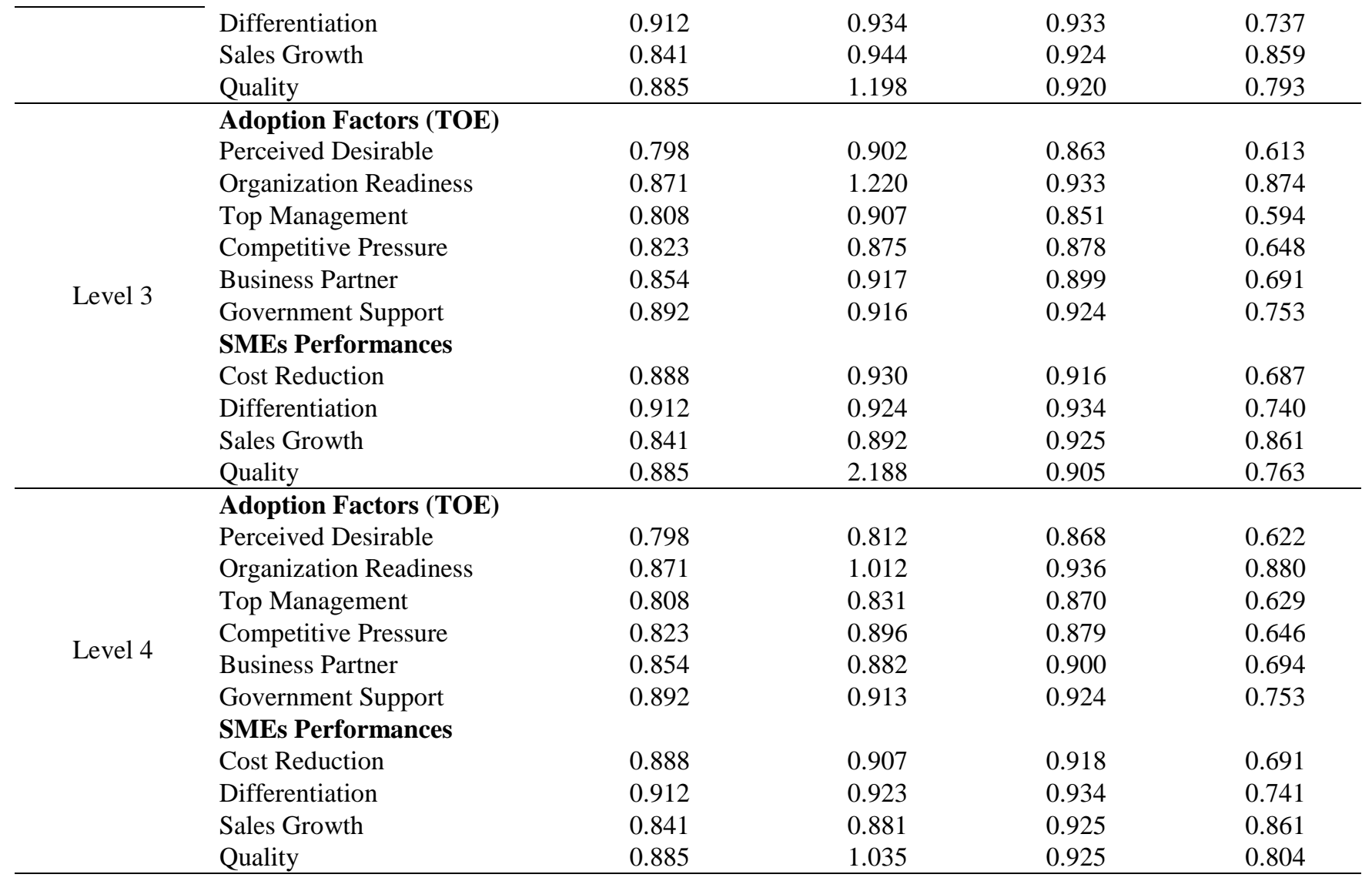

Table 3.

Formative latent variable value measurement

\begin{tabular}{clllll}
\hline $\begin{array}{c}\text { B2B E-Commerce } \\
\text { Adoption Level }\end{array}$ & Indicator & Weight & S.E. & VIF & Loading Factor \\
\hline \multirow{3}{*}{ Level 1 } & Level 1 A & 2.659 & 0.073 & 1.135 & 0.472 \\
& Level 1 B & 9.436 & 0.034 & 3.816 & 0.920 \\
& Level 1 C & 8.898 & 0.038 & 2.436 & 0.870 \\
& Level 1 D & 9.819 & 0.035 & 4.126 & 0.924 \\
\hline \multirow{2}{*}{ Level 2 } & Level 2 A & 8.881 & 0.033 & 3.081 & 0.870 \\
& Level 2 B & 8.808 & 0.03 & 3.129 & 0.871 \\
& Level 2 C & 9.53 & 0.031 & 3.637 & 0.895 \\
& Level 2 D & 8.304 & 0.034 & 3.373 & 0.873 \\
\hline \multirow{2}{*}{ Level 3 } & Level 3 A & 2.932 & 0.155 & 3.060 & 0.819 \\
& Level 3 C & 6.108 & 0.111 & 2.426 & 0.924 \\
\hline \multirow{2}{*}{ Level 4 } & Level 4 A & 4.68 & 0.055 & 1.595 & 0.754 \\
& Level 4 B & 7.523 & 0.047 & 1.799 & 0.835 \\
& Level 4 C & 6.092 & 0.051 & 1.873 & 0.824 \\
& Level 4 D & 6.531 & 0.048 & 1.784 & 0.809 \\
\hline
\end{tabular}




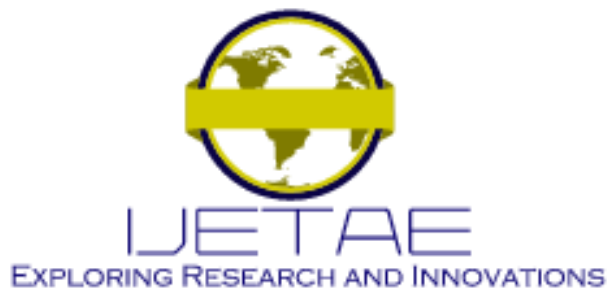

International Journal of Emerging Technology and Advanced Engineering

Website: www.ijetae.com (E-ISSN 2250-2459, Scopus Indexed, ISO 9001:2008 Certified Journal, Volume 11, Issue 08, August 2021)

Table 4.

The Impact of Technology-Organization-Technology Factors on E-commerce Adoption Level

\begin{tabular}{llcccc}
\hline Levels & \multicolumn{1}{c}{ Construct } & $\begin{array}{c}\text { Path } \\
\text { coefficients }\end{array}$ & $\begin{array}{c}\text { Standard } \\
\text { Deviation }\end{array}$ & T statistic & P-Value \\
\hline Level 1 & Perceived Desirable & 0.332 & 0.203 & 1.638 & 0.102 \\
& Organization Readiness & -0.186 & 0.204 & 0.910 & 0.363 \\
& Top Management & 0.526 & 0.234 & 2.247 & 0.025 \\
& Competitive Pressure & -0.069 & 0.193 & 0.358 & 0.720 \\
& Business Partner & 0.141 & 0.297 & 0.474 & 0.636 \\
& Government Support & -0.084 & 0.252 & 0.333 & 0.739 \\
\hline Level 2 & Perceived Desirable & 0.118 & 0.225 & 0.525 & 0.600 \\
& Organization Readiness & 0.012 & 0.275 & 0.043 & 0.965 \\
& Top Management & 0.603 & 0.234 & 2.574 & 0.010 \\
& Competitive Pressure & -0.358 & 0.232 & 1.543 & 0.123 \\
& Business Partner & 0.245 & 0.323 & 0.759 & 0.448 \\
& Government Support & 0.062 & 0.299 & 0.819 & 0.413 \\
\hline Level 3 & Perceived Desirable & 0.029 & 0.207 & 0.138 & 0.891 \\
& Organization Readiness & -0.162 & 0.267 & 0.606 & 0.545 \\
& Top Management & 0.489 & 0.239 & 2.050 & 0.041 \\
& Competitive Pressure & -0.035 & 0.209 & 0.169 & 0.866 \\
& Business Partner & 0.159 & 0.279 & 0.569 & 0.570 \\
& Government Support & 0.219 & 0.230 & 0.950 & 0.343 \\
\hline Level 4 & Perceived Desirable & 0.155 & 0.187 & 0.828 & 0.408 \\
& Organization Readiness & -0.150 & 0.308 & 0.485 & 0.628 \\
& Top Management & 0.444 & 0.197 & 2.247 & 0.025 \\
& Competitive Pressure & -0.097 & 0.189 & 0.515 & 0.607 \\
& Business Partner & 0.033 & 0.196 & 0.167 & 0.867 \\
& Government Support & 0.315 & 0.198 & 1.594 & 0.112 \\
\hline
\end{tabular}

\section{Hypothesis Testing.}

The SEM-PLS analysis shows the relationship between variables in SEM construct as follow,

Table 4 shows the factors that affect e-commerce adoption level of SMIs in Bogor. The result shows a very surprising outcome in which only the top management affects the e-commerce adoption level of SMIs across all 4 levels. Specifically, top management influences all four levels. Structural Model Assessment

The Structural model is evaluated by the R-square coefficient and path coefficient from the proposed research framework. The coefficient determination analysis explains how significant the independent variables' impact on the dependent variables - which the square of the correlation coefficient. Other than showing the relationship between variables, the coefficient determination analysis shows the independent path variable and its dependent variable. The following are the four models that tested to understand how many factors affect each B2B e-commerce adoption level and how B2B e-commerce adoption level affects SMIs' performance.

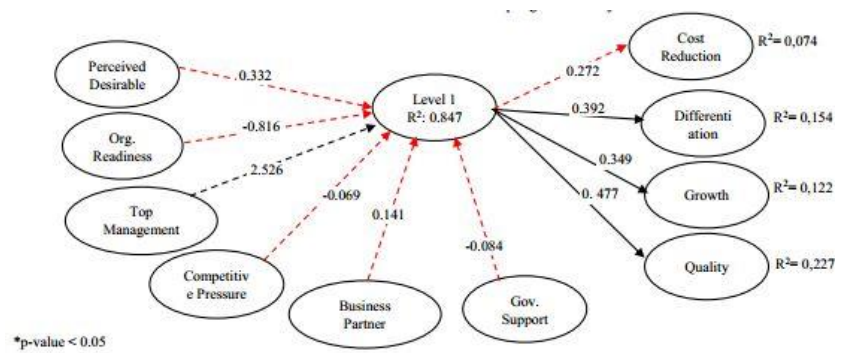

Figure 2. Structural model of Level 1

\section{B2B Level 1 Structural Model}

According to the analysis result of path coefficient value and $p$-value on the perceived desirable $(\beta=0.332$, $=0.102)$, organization readiness $(\beta=-0.887, \mathrm{p}=0.363)$, competitive pressure $(\beta=-0.069, \mathrm{p}=0.720)$, pressure from business partner $(\beta=0.141, p=0.636)$, government support $(\beta=-0.084, p=0.743)$ does not show any significant value. Therefore, the perceived desirable, organization readiness, top management, competitive pressure, business partner, government support does not have any impact on e-commerce adoption level 1. 


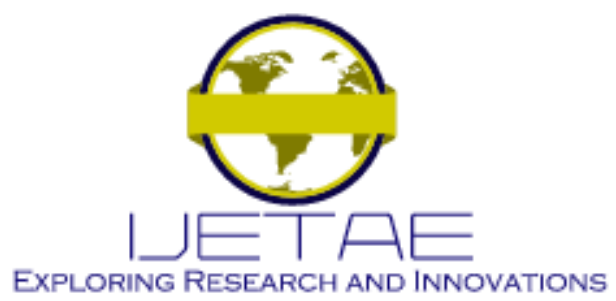

International Journal of Emerging Technology and Advanced Engineering

Website: www.ijetae.com (E-ISSN 2250-2459, Scopus Indexed, ISO 9001:2008 Certified Journal, Volume 11, Issue 08, August 2021)

However, the path coefficient value and p-value from top management $(\beta=0.526, \mathrm{p}=0.025)$ shows a significant positive value. It means, the higher the top management value, the higher the e-commerce adoption level 1 value. Nevertheless, the relation between e-commerce adoption level 1 on company performance shows significant positive value on path coefficient value and $p$-value of $(\beta=0.392, p$ $=0.084)$ on company differentiation, sales growth $(\beta=$ $0.349, \mathrm{p}=0.017)$, and quality $(\beta=0.477, \mathrm{p}=0.005)$. This indicates the e-commerce adoption level 1 affects the company differentiation, sales growth, and quality positively. However, the analysis result on cost reduction value shows insignificant value on the path coefficient value and $p$-value with $(\beta=0.272, p=0.292)$. Hence the level 1 adoption does not have any meaningful impact on cost reduction.

Figure 2 presents that Level 1 has an $\mathrm{R}^{2}$ value of 0,847 , which indicates that all four factors have an $84.7 \%$ contribution in affecting the Level 1 adoption. In contrast, the other $16.3 \%$ were affected by other variables not studied. $\mathrm{R}^{2}$ value on cost, differentiation, sales, and quality variables shows how significant the Level 1 adoption contribution on those variables.

\section{B2B Level 2 Structural Model}

On the e-commerce adoption level 2, the perceived desire variable $(\beta=0.118, \mathrm{p}=0.600)$, organization readiness $(\beta=0.012, p=0.965)$, competitive pressure $(\beta=$ $-0.358, \mathrm{p}=0.123)$, business partner pressure $(\beta=0.245, \mathrm{p}$ $=0.448)$, and government support $(\beta=0.062, \mathrm{p}=0.413)$, shows insignificant value. However, the top management support variable shows a positive significant value $(\beta=$ $0.603, p=0.010$ ). Thus, on the Level 2 , the only factor that affects SMI to adopt e-commerce is the top management support variable. The better the top management support, the more the SMI will

adopt e-commerce on the level 2. Moreover, the ecommerce adoption level 2 shows a significant positive value on company differentiation $(\beta=0.417, p=0.013)$, sales growth $(\beta=0.290, p=0.003)$, and quality $(\beta=0.457$, $\mathrm{p}=0.023)$. But a different result was shown for the cost reduction variable $(\beta=0.230, p=0.462)$. In conclusion, ecommerce adoption level 2 does not affect cost reduction.

Figure 3 shows that Level 2 has an $R^{2}$ value of 0,450 , which means all six factors affect $45 \%$ decision to adopt Level 2, and the other $55 \%$ is affected by other variables that are not studied. $\mathrm{R}^{2}$ value on cost, differentiation, sales growth, and quality indicates the significant contribution that Level 2 adoption gives to those variables.

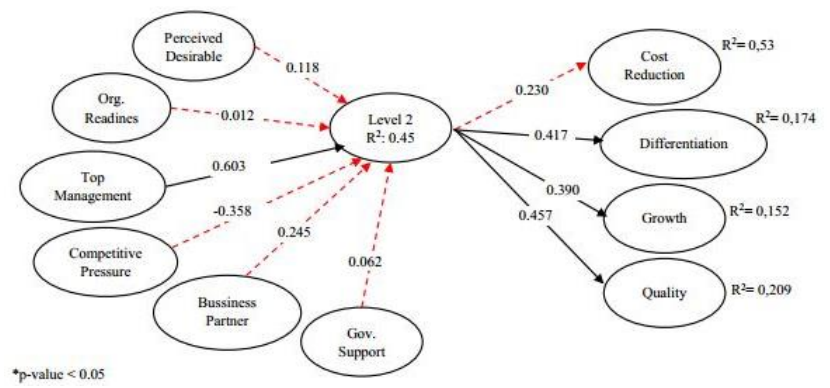

Figure 3 Structural model of Level 2

\section{Model Structural B2B Level 3}

The only variable that affects SMIs' Level 3 adoption is the top management, in which the impact is positive $(\beta=0$. $489, \mathrm{p}=0.041)$. This indicates that the better the top management of a company, the bigger the company's chance to adopt Level 3 e-commerce. Nonetheless, on the perceived desire $(\beta=0.029, \mathrm{p}=0.891)$, organization readiness $(\beta=-0.162, p=0.545)$, competitive pressure $(\beta=$ $-0.035, \mathrm{p}=0.866)$, business partner pressure $(\beta=0.159, \mathrm{p}$ $=0.570)$, and government support $(\beta=0.219, p=0.343)$, shows insignificant value on e-commerce adoption level 3 . The path coefficient and p-value analysis result on the adoption level 3 shows that the only affected variable is the sales growth. Yet, the cost reduction $(\beta=0.310, p=0.239)$, company differentiation $(\beta=0.366, \mathrm{p}=0.054)$, and quality $(\beta=0.403, p=0.225)$ does not give a significant result. Thus, adopting Level 3 e-commerce will help SMIs to increase their sales.

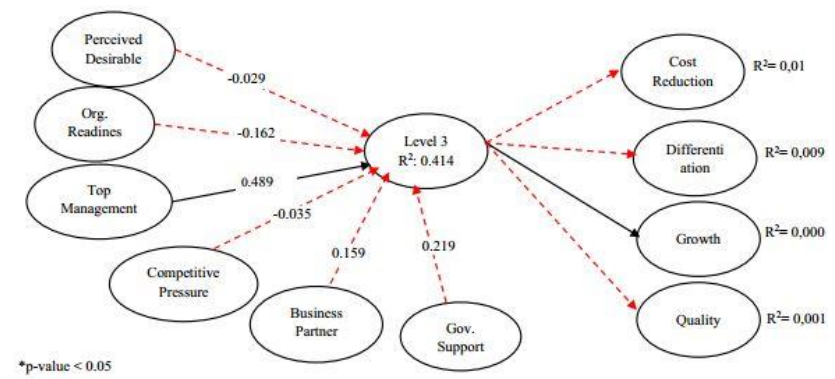

Figure 4. Structural model of Level 3

Figure 4 shows that Level 3 has $R^{2}$ value of 0,413 , which means all five factors contribute to $41,3 \%$ influence on Level 3 e-commerce adoption, and the rest $58,7 \%$ is influenced by other variables that are not studied. $\mathrm{R}^{2}$ on the cost reduction, differentiation, sales growth, and quality shows the significance of Level 3 contribution on each variable. 


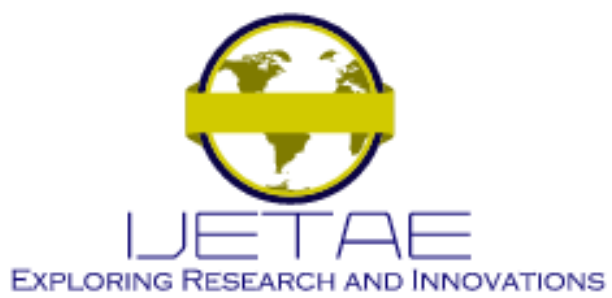

International Journal of Emerging Technology and Advanced Engineering

Website: www.ijetae.com (E-ISSN 2250-2459, Scopus Indexed, ISO 9001:2008 Certified Journal, Volume 11, Issue 08, August 2021)

Based on the value, Level 3's most immense contribution goes to the sales growth variable and insignificant to the cost reduction variable.

\section{B2B Level 4 Structural Model.}

Figure 5 shows the structural model of level 4 on ecommerce adoption level 4 , the perceived desire variable $(\beta$ $=0.155, \mathrm{p}=0.408)$, organization readiness $(\beta=-0.150, \mathrm{p}$ $=0.628)$, competitive pressure $(\beta=-0.358, \mathrm{p}=0.123)$, business partner pressure $(\beta=-0.097, \mathrm{p}=0.607)$, and government support $(\beta=0.315, p=0.112)$, shows insignificant value. Yet, the top management support variable shows a significant positive value $(\beta=0.444, \mathrm{p}=$ $0.025)$. Therefore, on the level 4 , only the top management support affects the e-commerce adoption. The stronger the top management support, the more the willingness to implement level 4 e-commerce adoption. Moreover, the ecommerce adoption level 4 shows significant positive value on the cost reduction $(\beta=0.455, \mathrm{p}=0.012)$, company differentiation $(\beta=0.505, \mathrm{p}=0.006)$, sales growth $(\beta=0.525, p=0.003)$, and quality $(\beta=0.493, p=$ 0.008). This indicates that e-commerce adoption level 4 will improve the cost reduction, company differentiation, sales growth, and quality.

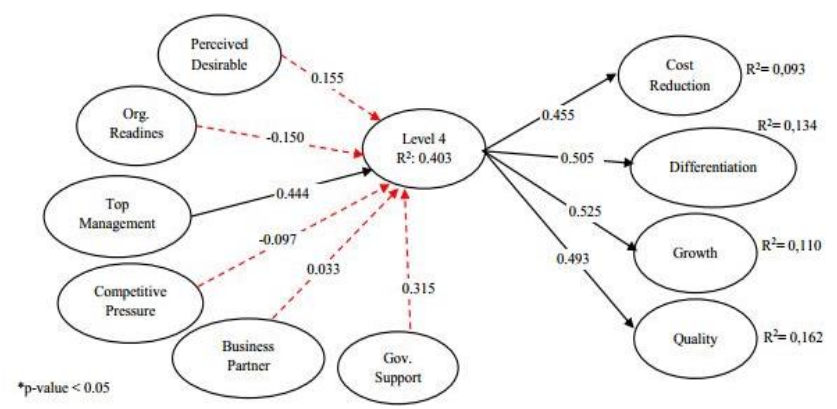

Figure 5. Structural model of Level 4

Figure 5 shows the Level 4 adoption has an $\mathrm{R}^{2}$ value of 0,414 , which means three factors have $41,4 \%$ influence on a company to adopt Level 4 e-commerce, and the other $58,6 \%$ influenced by other variables that are not studied. $\mathrm{R}^{2}$ on the cost reduction variable, differentiation, sales growth, and the quality shows how notable the Level 4 adoption contribution is. Based on the $\mathrm{R}^{2}$ value, Level 4 has the most significant contribution to sales growth and the least on cost reduction.

\section{DISCUSSIONS}

This research aims to inspect the e-commerce adoption level of SMIs in Bogor by testing the causality of several factors to the e-commerce adoption using the TOE (Technology-Organization-Environment) theory and what is the impact that each e-commerce adoption level gives to the business unit performance. The analysis result shows evidence that only top management support can affect a business to adopt e-commerce. This result is shown on every B2B e-commerce adoption level that were tested. Whence, the stronger the SMIs top management support, the bigger the chance of the SMI to adopt e-commerce on every level of adoption. This result is different from the researches of [6] and [7] which provides more driving factors for SMIs to adopt e-commerce. This contrasting result might relate to the different business sizes that were analysed. This research focuses on the adoption level on SMIs that does not have a rigid bureaucracy like those of big company. That is why the role of the top management is very important because of the small nature of the business. On the other hand, this research agrees that the government does not hold prominent role in pushing SMIs to adopt e-commerce.

The analysis result on each e-commerce adoption level is different. The impact of e-commerce adoption level 1 to 3 does not have significant impact on cost reduction of SMI. Therefore, when a business unit adopt e-commerce level 1 to 3 , the cost of marketing, advertising, sales, and service are not reduced. However, level 4 affects the cost reduction significantly. The Level 4 is the highest level of ecommerce adoption, where all transaction process and communication are centralized within the website. That is why, SMIs that have already adopted level 4 e-commerce adoption will experience significant cost reduction.

The impact of e-commerce adoption on company differentiation and quality is significant on level 1, 2, and 4. When a SMI adopts e-commerce on the lowest level or the highest, their company differentiation and quality will significantly improve. However, on e-commerce adoption level 3, where a business uses a website, including social media to communicate and inform consumers and partners, and has customization service and online payment, the company differentiation and quality is not really affected. The number of competitors makes business units with level 3 e-commerce adoption dominated the market. 


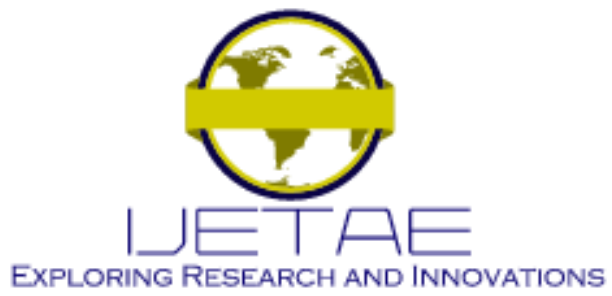

International Journal of Emerging Technology and Advanced Engineering

Website: www.ijetae.com (E-ISSN 2250-2459, Scopus Indexed, ISO 9001:2008 Certified Journal, Volume 11, Issue 08, August 2021)

Therefore, the e-commerce adoption on this level does not affect the company differentiation and quality.

Lastly, the impact of e-commerce adoption on sales growth. The analysis result shows consistently that on every e-commerce adoption level have positive impact on the growth of the company. This indicates that on every adoption level, SMIs will experience significant sales growth.

Looking at all the levels, B2B Level 4 has a very significant influence on the four indicators of e-commerce implementation. The test result appears due to several factors, one of which is the SMIs' unpreparedness in using e-commerce in their business. Early-stage businesses cannot optimize the massive potential of e-commerce. This incompetence translates to a minor influence, even though the effect of competitive pressure from competitors is not too significant. Other than that, the government support also hampers the pace of e-commerce adoption because only some can enjoy the luxury.

\section{CONCLUSION}

In conclusion, this study finds that the B2B e-commerce implementation will significantly impact the top management. The application will also have a notable impact on every other indicator other than cost reduction since e-commerce adoption will increase SMIs' in their transaction cost.

Furthermore, the result shows that the higher the B2B ecommerce adoption level, the higher the competitive advantage an SMI will get. However, even though it is positive, the impact is not as significant as imagined. From the survey, internally, SMIs have the urge to advance their adoption level. Many of them are already on Level 1 and 2, some on Level 3, and very few on Level 4. Their urge also indicates that SMIs are more focused on their growth, allowing them to compete in the market. It will also allow them to broaden their market and eventually increase their sales and revenue. The next target is quality and cost reduction as a form of competitive advantage.

The fact that e-commerce can be adopted in various stages - which in this paper symbolized as Level 1-4 - leads to the knowledge that every level will generate distinct advantages. The result also stated that, although SMIs have internal barriers to adopt B2B e-commerce, external factors do not pose a significant impact on SMIs' shift to ecommerce. This will make SMIs focused more on internal problems such as creating e-commerce accounts, digital payment, and other organization readiness relating to the ecommerce implementation.
The more SMIs ready to use e-commerce in their business, the more significant the impact they will get.

\section{STUDY IMPLICATIONS}

\section{Theoretical Implications}

In terms of theoretical implication, this study can be considered as original in the scope of B2B e-commerce, especially in SMIs. From the critical exposition of the literature, it is clear that empirical studies on the B2B ecommerce problem are just starting to emerge in developed countries and less often in the developing ones [8]. Previous studies primarily focused on the general view about SMIs B2B e-commerce adoption or the relation between information technology adoption and competitive advantage.

This research was conducted at the lowest level, which is at the regional level, hoping to contribute to the adoption of B2B e-commerce and its relations with e-commerce adoption level by SMIs and its impact on the competitive advantage. Furthermore, the findings confirm that different levels of B2B e-commerce adoption resulted in various competitive advantages. This research also contributes to B2B e-commerce theory by examining the SMIs ecommerce adoption in Bogor. Consequently, this research contributed strictly to B2B e-commerce in Bogor's SMIs.

\section{Practical Implication}

On the practical implication of the study, essential points can be drawn by SMIs owners from the findings to help them understand the situation they are in as they go through various stages of B2B e-commerce adoption in Bogor. This study also provides beneficial implications to the government, non-governmental organizations, and other SMIs-related institutions of what B2B e-commerce can do to their businesses. SMIs that are sceptical about adopting $\mathrm{B} 2 \mathrm{~B}$ e-commerce need to rethink and examine the situation further as implementing B2B e-commerce will become a necessity for most businesses in the future. Even though it is likely that it takes time to see the result, it should not prevent SMIs from adapting to B2B e-commerce at an early stage.

The analysis result of this study reveals that a higher level of B2B e-commerce adoption generates a more significant competitive advantage, and this will motivate SMIs to shift and adopt higher technology approaches to increase their leverage in the market. Also, this research shows that the adoption of B2B e-commerce can help SMIs develop their business. 


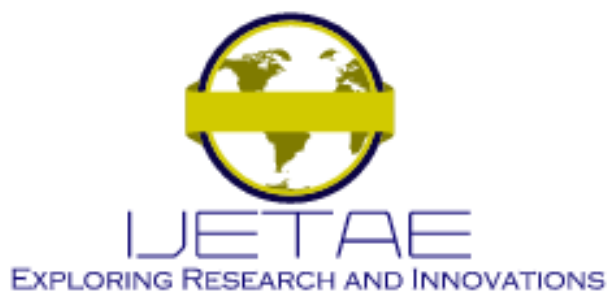

International Journal of Emerging Technology and Advanced Engineering Website: www.ijetae.com (E-ISSN 2250-2459, Scopus Indexed, ISO 9001:2008 Certified Journal, Volume 11, Issue 08, August 2021)

E-commerce adoption can increase market share and will eventually affect sales and revenue. Therefore, encouragement in technology investment is necessary.

However, technology-service providers need to diversify their segments according to the SMIs' adoption level to attract their market better. It will be helpful to analyse SMIs outside of Bogor. It will provide information about whether B2B e-commerce adoption is affected by a region's economic development and will allow IT consultants and vendors to adjust their services accordingly.

This study's findings will also benefit the e-commerce service providers who wish to start their operations in a new country as this paper has looked at one of the regions' characteristics. The government can use this research to develop a new policy to persuade SMIs to adopt B2B ecommerce or advance their e-commerce level, especially on the regional scale. Generalization cannot be used in ecommerce adoption. Therefore, the regional government should help in pushing the e-commerce adoption of SMIs. There are at least two things that the government can do. First, increase the awareness of e-commerce and its benefit to SMIs. Second, eliminate the barrier to adopt B2B ecommerce by providing public infrastructure and technical assistance to SMIs.

\section{REFERENCES}

[1] M. H. Abdulwahab and R. A. Al-damen, "The Impact of Entrepreneurs 'Characteristics on Small Business Success at Medical Instruments Supplies Organizations in Jordan Amman Arab University Business Administration Department Amman Arab University," Int. J. Bus. Soc. Sci., vol. 6, no. 8, pp. 164175Abdulwahab, M. H., Al-damen, R. A. (2015), 2015.

[2] G. F. Dianari, "Pengaruh E-Commerce Terhadap Pertumbuhan Ekonomi Indonesia," Bina Ekon. Ilm. Fak. Ekon. Univ. Katolik Parahyangan, vol. 22, no. 1, pp. 43-62, 2018.

[3] V. Sundaram, D. Ramkumar, and P. Shankar, "Impact of E-Service Quality on Customer Satisfaction and Loyalty Empirical Study in India Online Business," Kinerja, vol. 21, no. 1, p. 48, 2017.

[4] W. Febriantoro, "Kajian Dan Strategi Pendukung Perkembangan ECommerce Bagi Umkm Di Indonesia," Manajerial J. Manaj. dan Sist. Inf., vol. 17, no. 2, pp. 184-207, 2018.

[5] M. Kartiwi, H. Hussin, M. A. Suhaimi, M. R. Mohamed Jalaldeen, and M. R. Amin, "Impact of external factors on determining Ecommerce benefits among SMEs in Malaysia," J. Glob. Entrep. Res., vol. 8, no. 1, pp. 1-12, 2018.

[6] C. E. Ocloo, H. Xuhua, J. Akaba, S., Shi, and D. K. Worwui-Brown, "The Determinant Factors of Business to Business (B2B) ECommerce Adoption in Small- and Medium-Sized Manufacturing Enterprises,” J. Glob. Inf. Technol. Manag., 2020.
[7] I. Elbeltagi, H. Hamad, J. Moizer, and M. A. Abou-Shouk, "Levels of Business to Business E-Commerce Adoption and Competitive Advantage in Small and Medium-Sized Enterprises: A Comparison Study Between Egypt and the United States,” J. Glob. Inf. Technol. Manag., vol. 19, no. 1, pp. 6-25, Jan. 2016.

[8] L. A. Lefebvre, É. Lefebvre, E. Elia, and H. Boeck, "Exploring B-toB e-commerce adoption trajectories in manufacturing SMEs," Technovation, vol. 25, no. 12, pp. 1443-1456, 2005.

[9] M. Moon and D. Norris, "Does Managerial Orientation Matter? The Adoption of Reinventing Government and E-Government at the Municipal Level,” Inf. Syst. J., vol. 15, pp. 43-60, Jan. 2005.

[10] A. Qosasi, E. Maulina, M. Purnomo, A. Muftiadi, E. Permana, and F. Febrian, "The impact of Information and Communication Technology capability on the competitive advantage of small businesses," Int. J. Technol., vol. 10, no. 1, pp. 167-177, 2019.

[11] P. K. Ningtyas, B. Sunarko, and Jaryono, “Analisis Faktor Yang Mempengaruhi Adopsi E-Commerce Dan Pengaruhnya Terhadap Kinerja UMKM,” Performance, vol. 21, no. 1, pp. 95-107, 2015.

[12] A. Noviani Hanum and A. Sinarasri, "Analisis Faktor-Faktor Yang Mempengaruhi Adopsi E Commerce Dan Pengaruhnya Terhadap Kinerja Umkm (Studi Kasus Umkm Di Wilayah Kota Semarang), Maksimum, vol. 8, no. 1, p. 1, 2018.

[13] X. Duan, H. Deng, and B. Corbitt, "Evaluating the critical determinants for adopting e-market in Australian small-and-medium sized enterprises," Manag. Res. Rev., vol. 35, no. 3/4, pp. 289-308, Jan. 2012.

[14] R. Govindaraju and D. R. Chandra, "E-commerce adoption by Indonesian small, medium, and micro enterprises (SMMEs): Analysis of goals and barriers," in 2011 IEEE 3rd International Conference on Communication Software and Networks, ICCSN 2011, 2011, pp. 113-117.

[15] M. I. Effendi, D. Sugandini, Y. Istanto, R. Arundati, and T. Adisti, The Technology-Organization-Environment Framework: Adopsi Teknologi Pada UKM, no. November. Zahir Publishing, 2020.

[16] N. Vasić, M. Kilibarda, M. Andrejić, and S. Jović, "Satisfaction is a function of users of logistics services in e-commerce," https://doi.org/10.1080/09537325.2020.1849610, vol. 33, no. 7, pp. 813-828, 2020.

[17] J. Bolongkikit, J. H. Obit, J. G. Asing, and G. H. Tanakinjal, “An Exploratory Research of the Usage Level of E-commerce among Small and Medium Enterprises (SMEs) in the West Coast of Sabah, Malaysia," J. Internet Bank. Commer., vol. 11, no. 2, pp. 1-12, 2006.

[18] A. A. Al-Tit, "E-commerce drivers and barriers and their impact on e-customer loyalty in small and medium-sized enterprises (Smes)," Bus. Theory Pract., vol. 21, no. 1, pp. 146-157, 2020.

[19] P. K. Singh and J. K. Pattanayak, "Linking of Customer Satisfaction with Shareholders' value: A Review," Glob. J. Financ. Manag., vol. 6, no. 5, pp. 403-412, 2014.

[20] P. Chwelos, I. Benbasat, and A. S. Dexter, "Empirical Test of an EDI Adoption Model," Inf. Syst. Res., vol. 2, no. 604, pp. 304-321, 2000.

[21] F. H. O. Hamed, M. S. Madihah, and S. Kamaruzzaman, "Trustworthy E-Commerce model for small medium enterprises (SMEs)," Int. J. Eng. Technol., vol. 7, no. 4, pp. 135-140, 2018. 


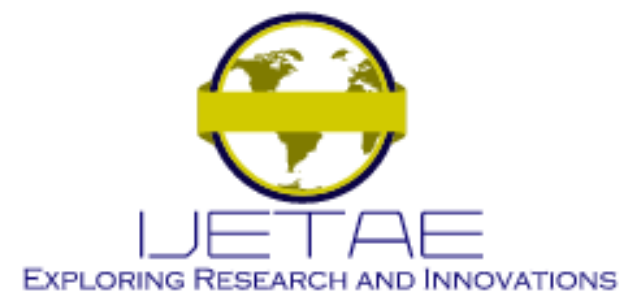

International Journal of Emerging Technology and Advanced Engineering Website: www.ijetae.com (E-ISSN 2250-2459, Scopus Indexed, ISO 9001:2008 Certified Journal, Volume 11, Issue 08, August 2021)

[22] L. Van Huy, F. Rowe, D. Truex, and M. Q. Huynh, “An empirical study of determinants of E-Commerce adoption in SMEs in Vietnam: An Economy in Transition,” J. Glob. Inf. Manag., vol. 20, no. 3, pp. 23-54, 2012.

[23] J. T. Al-Tarawneh, M. S. I. Saadon, and A. N. Maqableh, "The Relationship Between Human Resource Practices and Organizational Performance and Their Operation in Light of the Development of Using Big Data Technology," Stud. Comput. Intell., vol. 974, pp. 371-392, 2021.

[24] J. Guo, S. Zhou, J. Chen, and Q. Chen, "How information technology capability and knowledge integration capability interact to affect business model design:A polynomial regression with response surface analysis," Technol. Forecast. Soc. Change, vol. 170, p. 120935 , Sep. 2021.

[25] I. Tzavlopoulos, K. Gotzamani, A. Andronikidis, and C. Vassiliadis, "Determining the impact of e-commerce quality on customers' perceived risk, satisfaction, value and loyalty," Int. J. Qual. Serv. Sci., vol. 11, no. 4, pp. 576-587, Dec. 2019.

[26] S. Pavic, S. C. L. Koh, M. Simpson, and J. Padmore, "Could ebusiness create a competitive advantage in UK SMEs?," Benchmarking, vol. 14, no. 3, pp. 320-351, 2007.

[27] K. Krell and S. Matook, "Competitive advantage from mandatory investments: An empirical study of Australian firms,” J. Strateg. Inf. Syst., vol. 18, no. 1, pp. 31-45, 2009.

[28] T. S. H. Teo and Y. Pian, "A contingency perspective on Internet adoption and competitive advantage," Eur. J. Inf. Syst., vol. 12, no. 2, pp. 78-92, 2003.

[29] E. Muiz and S. Sunarta, "Penerapan Strategi Diferensiasi Memiliki Pengaruh terhadap Kinerja Perusahaan," J. Ekobis Ekon. Bisnis Manaj., vol. 8, no. 1, pp. 26-39, 2020.

[30] M. M. N. Absar, R. Srivastava, and S. Akhter, "Leadership through differentiation: Hero's journey with Niloy Motors in the motorcycle industry of Bangladesh,” Emerald Emerg. Mark. Case Stud., vol. 11, no. 1, pp. 1-20, Mar. 2021.

[31] K. Wu, K. Da, and W. Ma, "The Impact of Intelligent Science and Technology on Human Society: Appeals of Institutional System," Proc. 2020, Vol. 47, Page 38, vol. 47, no. 1, p. 38, May 2020.
[32] S. Bhattacharya, J. Gong, and S. Wattal, "Competitive Poaching in Search Advertising: A Randomized Field Experiment," SSRN Electron. J., Jan. 2019.

[33] Z. Ye, N. H. Hashim, F. Baghirov, and J. Murphy, "Gender Differences in Instagram Hashtag Use," https://doi.org/10.1080/19368623.2018.1382415, vol. 27, no. 4, pp. 386-404, May 2017.

[34] Q. L. <p>Yongsai Yan, "An Overview of the Application of Data Mining Technology in E-commerce," Acad. J. Eng. Technol. Sci., vol. 2, no. 2, pp. 76-88, Aug. 2019.

[35] T. Deitiana, "Pengaruh rasio keuangan dan pertumbuhan penjualan terhadap dividen dan implikasinya pada harga saham," J. Akunt., vol. XVI, no. 02, pp. 191-208, 2012.

[36] H. Helmalia and A. Afrinawati, "Pengaruh E-Commerce Terhadap Peningkatan Pendapatan Usaha Mikro Kecil Dan Menengah Di Kota Padang," JEBI (Jurnal Ekon. dan Bisnis Islam., vol. 3, no. 2, pp. 237-246, 2018.

[37] W. A. Al-Suraihi, A.-H. A. Al-Suraihi, I. Ibrahim, A. Al-Tahitah, and M. Abdulrab, "The Effect of Customer Relationship Management on Consumer Behavior: A Case of Retail Industry in Malaysia,” Int. J. Manag. Hum. Sci., vol. 4, no. 3, pp. 32-40, 2020.

[38] Y. Zeng, H. Guo, Y. Yao, and L. Huang, "The formation of agricultural e-commerce clusters: A case from China," Growth Change, vol. 50, no. 4, pp. 1356-1374, Dec. 2019.

[39] J. Connell et al., "The importance of content and face validity in instrument development: lessons learnt from service users when developing the Recovering Quality of Life measure (ReQoL) page 10," Qual. Life Res., vol. 27, no. 7, pp. 1893-1902, 2018.

[40] M. Elvén, J. Hochwälder, E. Dean, O. Hällman, and A. Söderlund, "Criterion scores, construct validity and reliability of a web-based instrument to assess physiotherapists' clinical reasoning focused on behaviour change: 'Reasoning 4 Change,"' AIMS Public Heal., vol. 5, no. 3, pp. 235-259, 2018. 